\title{
ANALISIS PERSEPSI PETANI TERHADAP PEMANFAATAN BOKASHI PADA PERTANAMAN PADI SAWAH
}

\section{Farmers Perception Analysis toward Bokashi Use on Rice Cultivation}

\author{
Hasan Basri \\ Balai Pelatihan Pertanian (BPP) Lampung \\ Email: hasanbasrilpg@gmail.com
}

\begin{abstract}
The purpose of this study is to analyze the implementation level of introduce technology of bokashi on rice cultivation. This study was conducted in the village Kuripan Sub Penengahan, South Lampung regency. Technique of data collecting conducted by field observation and interview by using of quizioner. Determine of sample conducted with purposive sampling. Data analysed using non parametric analysis (rating scale). Result of the study relevead that the public interest of farmer very high to bokashi applying. Based to result of evaluation about perception of farmer to technology of making and applying of bokashi in rice cultivation, applying has $72,0 \%$ high respons and $28,0 \%$ do not respons.
\end{abstract}

Keywords: farmer, perception, bokashi, rice

\section{PENDAHULUAN}

Saat ini pemikiran sebagian besar petani Indonesia selalu bertumpu pada penggunaan pupuk kimia (anorganik) dalam mengusahakan tanaman. Sedangkan penggunaan pupuk anorganik dengan takaran yang melebihi ketentuan membuat berubahnya tekstur dan struktur tanah. Tanah menjadi sulit diolah dan tanah bersifat masam. Kondisi tanah masam akan menghambat mobilisasi unsur hara karena unsur hara akan terikat, imbasnya suplai nutrisi ke tanaman semakin berkurang sehingga produktivitas tanaman menjadi rendah. Jalan keluar yang ditempuh petani dengan menambah dosis pupuk anorganik sehingga kerusakan semakin bertambah parah (Nasir, 2008).

Strategi pemerintah dengan memperdayakan pola pertanian rakyat dengan nilai komparatif dan kompetitifnya mulai dilakukan untuk menghindarkan Negara dari bahaya yang lebih jauh. Penggunaan pupuk organik (Bokashi) dimaksud untuk mengganti ketergantungan pada pupuk anorganik. Upaya penggunaan pupuk organik berkualitas dengan teknologi sederhana perlu dilakukan agar masyarakat pertanian Indonesia menjadi mandiri sebagi kunci sukses penyediaan bahan pangan yang cukup. Hal ini 
sejalan dengan konsep pembangunan pertanian ke depan diharapkan mampu menjaga kelestarian sumberdaya alam dan lingkungan.

Secara umum beberapa persepsi petani terhadap sistim pertanian organik bahwa dengan menggunakan bahan-bahan organik yang telah di daur ulang sebagai sarana produksi dalam berusahatani, maka secara perlahanlahan dapat memperbaiki kembali kondisi lahan yang telah mengalami degradasi untuk berproduksi.

Selain dari pada itu, persepsi petani bahwa pertanian organik yang ramah lingkungan merupakan salah satu alternatif untuk mengurangi ketergantungan terhadap penggunaan sarana produksi sintetik. Pemanfaatan bahan organik merupakan contoh nyata keberhasilan penerapan sistim pertanian yang selaras dengan alam.

Pengkajian ini bertujuan untuk mengetahui sejauh mana persepsi petani terhadap penggunaan bokashi pada pertanaman padi sawah.

\section{METODE PENELITIAN}

Pengkajian dilaksanakan di desa Kuripan, Kecamatan Penengahan, Kabupaten Lampung Selatan dimulai bulan Agustus sampai dengan November 2015. Sementara teknik pengumpulan data yang dilakukan dengan cara observasi lapangan yang dilanjutkan dengan wawancara terhadap petani responden dengan menggunakan kuisioner (daftar pertanyaan). Data yang diambil berupa data primer (data dari petani) dan data sekunder yang diperoleh dari kantor desa , penyuluh setempat dan instansi yang terkait.

Dalam penentuan sampel (responden) digunakan sistim purposif sampling (penunjukan secara langsung) yaitu dari keseluruhan populasi petani padi sawah yang tergabung dalam Kelompok Tani Sri Maju II Desa Kuripan, Kecamatan Penengahan, Kabupaten Lampung Selatan (Suparmin, 2007). Data yang diperoleh berupa data primer dari petani, kemudian direkapitulasi dan ditabulasi untuk mendapatkan rata-rata atau gambaran tentang respon/tanggapan petani secara keseluruhan tentang penggunaan bokashi dalam pertanian orgnik. Adapun analisis data yang digunakan adalah analisis non parametrik yaitu dengan menggunakan skala nilai (rating scale), dengan menggunakan rumus skala nilai sebagai berikut:

Total nilai yang diperoleh

Total nilai = --------------------------------- × $100 \%$

136 | Hasan Basri, Analisis Persepsi Petani terhadap... 


\section{HASIL DAN PEMBAHASAN}

\section{Umur Petani}

Umur petani merupakan sesuatu yang sangat urgen dalam menentukan keberhasilan suatu usahatani. Berdasarkan hasil wawancara yang dilakukan kepada petani responden, maka penggolongan umur petani disajikan pada Tabel 1.

Tabel 1. Umur Petani

\begin{tabular}{cccc}
\hline No. & Umur (Tahun) & Jumlah (Orang) & Persentase (\%) \\
\hline 1. & $20-29$ & 2 & 8,00 \\
2. & $30-39$ & 12 & 48,00 \\
3. & $40-49$ & 6 & 24,00 \\
4. & $50-59$ & 3 & 12,00 \\
5. & $\geq 60$ & 1 & 4,00 \\
\hline & Jumlah & 25 & 100 \\
\hline
\end{tabular}

Sumber : Data Primer setelah diolah, 2015

Berdasarkan Tabel 1 terlihat bahwa umur produktif petani responden yang ada di desa Kuripan Kecamatan Penengahan pada berumur antara 20 29 (2 org); 30 - 39(12 org); 40 - 49 (6 org) sebanyak 20 orang (80,00\%), yang berarti sangat berpeluang dalam upaya peningkatan produktifitas melalui kemampuan berusahatani. Jika dilihat berdasarkan penggolongan umur produktif dan tidak produktif, maka sebagian besar petani responden berada dalam katagori umur produktif, dimana kisaran umur produktif berkisar antara 15 - 55 tahun (Rochani dkk, 2004). Pada umur ini, kemampuan fisik petani sangat berpengaruh untuk bekerja secara optimal.

\section{Tingkat Pendidikan}

Tingkat pendidikan formal petani sangat berpengaruh terhadap kemampuan dalam meresponsuatu inovasi. Makin tinggi tingkat pendidikan formasl petani, diharapkan makin rasional pola pikir dan daya nalarnya. Dengan pendidikan yang semakin tinggi, maka semakin lebih mudah merubah sikap dan perilaku untuk bertindak lebih rasional. Adapun tingkat pendidikan formal petani dapat disajikan pada Tabel 2.

Tabel 2 menunjukkan bahwa sebagian besar petani responden di Desa Kuripan Kecamatan Penengahan telah menempuh pendidikan formal walaupun masih tergolong pada tingkat pendidikan SLTP, sehingga dapat dikatakan bahwa sumberdaya manusia (SDM) petani masih tergolong rendah, tingkat pendidikan petani yang rendah merupakan salah satu penyebab sulitnya penerapan teknologi pertanian di lapangan.

Nuhung (2003) menyatakan bahwa pengelolaan usahatani secara tradisional merupakan indikasi lemahnya kualitas SDM masyarakat pertanian di Indoensia. Untuk mengatasi masalah tersebut perlu diupayakan pembinaan secara terus menerus oleh semua pihak terkait terutama penyuluh pertanian. 
Semakin tinggi tingkat pendidikan petani, maka wawasan berpikirnya juga semakin luas dan tentunya akan lebih cepat dalam menerima suatu inovasi yang disampaikan. Salikin (2003) menyatakan bahwa pengembangan SDM pertanian sebagai pelaku utama pembangunan pertanian sangat diharapkan dan merupakan suatu investasi masa depan menuju pertanian berkelanjutan.

Tabel 2. Tingkat Pendidikan Formal Petani

\begin{tabular}{cccc}
\hline No. & Pendidikan & Jumlah (Orang) & Persentase (\%) \\
\hline 1. & Tidak tamat SD & 2 & 10,00 \\
2. & SD & 8 & 24,00 \\
3. & SLTP & 11 & 44,00 \\
4. & SLTA & 4 & 16,00 \\
\hline & Jumlah & 25 & 100 \\
\hline
\end{tabular}

Sumber: Data Primer Setelah Diolah, 2015

\section{Tanggungan Keluarga}

Dalam melaksanakan kegiatan usahatani jumlah tanggungan keluarga merupakan sumber tenaga kerja yang dapat diandalkan. Di lokasi pengkajian menunjukkan bahwa tanggungan keluarga petani berkisar antara $2-4$ orang per keluarga. Untuk lebih jelasnya dapat dilihat pada Tabel 3 berikut:

\section{Tabel 3. Jumlah Tanggungan Keluarga Petani}

\begin{tabular}{cccc}
\hline No. & Jumlah Tanggungan (Orang) & Jumlah (Orang) & Persentase (\%) \\
\hline 1. & $1-2$ & 4 & 16,00 \\
2. & $3-4$ & 16 & 64,00 \\
3. & $5-6$ & 5 & 20,00 \\
\hline & Jumlah & 25 & 100 \\
\hline
\end{tabular}

Sumber: Data Primer Setelah Diolah, 2015

Tabel 3 menunjukkan bahwa sebagian besar petani responden di Desa Kuripan Kecamatan Penengahan Kabupaten Lampung Selatan mempunyai tanggungan keluarga $3-4$ orang $(64,00 \%)$. Hal ini menunjukan bahwa kebutuhan tenaga kerja yang berasal dari luar lingkungan keluarga tidak terlalu dibutuhkan (Salikin, 2003).

\section{Luas Lahan Garapan Usahatani}

Salah satu faktor produksi yang utama dalam mendukung usahatani dan sumber pendapatan petani adalah laghan. Luas kepemilikan lahan garapan petani responden dapat disajikan pada Tabel 4.

Tabel 4 menunjukkan bahwa sebagian besar petani responden di Dusun Banyu Urip Desa Kuripan memiliki lahan garapan yang relative sempit (0,2 hektar $=10$ orang). Sempitnya luas garapan tersebut karena petani responden, sebagian besar merupakan memiliki lahan dari harta warisan yang turun temurun yang harus dibagi-bagi. Lahan garapan yang sempit juga menjadi kendalam dalam pembangunan pertanian (Nuhung, 2003).

138 | Hasan Basri, Analisis Persepsi Petani terhadap... 
Tabel 4. Luas Lahan Garapan Usahatani Padi

\begin{tabular}{cccc}
\hline No. & Luas Garapan (Ha) & Jumlah (Orang) & Jumlah (Ha) \\
\hline 1. & 0,15 & 5 & 0,75 \\
2. & 0,20 & 10 & 2,00 \\
3. & 0,25 & 6 & 1,50 \\
4. & 0,50 & 4 & 2,00 \\
\hline & Jumlah & 25 & 6,25
\end{tabular}

Sumber: Data Primer Setelah Diolah, 2015

\section{Pengalaman Berusahatani}

Respon, tanggapan dan penerimaan petani terhadap suatu inovasi teknologi bergantung pada pengalaman petani, semakin lama petani dalam berusahatani, maka tingkat respon terhadap suatu teknologi akan semakin tinggi (Nuhung, 2003). Pengalaman berusahatani responden dapat disajikan pada Tabel 5.

Tabel 5. Pengalaman berusahatani padi petani responden di Desa Kuripan Kecamatan Penengahan Kabupaten Lampung Selatan.

\begin{tabular}{cccc}
\hline No. & $\begin{array}{c}\text { Pengalaman Berusahatani } \\
\text { (Tahun) }\end{array}$ & Jumlah (Orang) & Persentase (\%) \\
\hline 1. & $1-3$ & 2 & 8,0 \\
2. & $4-6$ & 4 & 16,0 \\
3. & $7-9$ & 17 & 68,0 \\
4. & $>9$ & 2 & 8,0 \\
\hline & Jumlah & 25 & 100 \\
\hline
\end{tabular}

Sumber: Data Primer Setelah Diolah, 2015

Terlihat jelas pada Tabel 5 bahwa petani responden di Desa Kuripan, Kecamatan Penengahan, Kabupaten Lampung Selatan sebagian besar (68,0\%) telah mempunyai pengalaman berusahatani selama 7 - 9 tahun. Sesuai dengan hasil survey, jumlah petani responden yang berusahatani padi sawah sudah ada yang menggunakan pupuk organik walaupun jumlahnya masih terbatas.

\section{Evaluasi Tingkat Persepsi atau Respon Petani terhadap Pemanfaatan Bokashi dalam Pertanaman Padi Sawah}

Dalam mengukur efektifitas kegiatan penyuluhan pertanian khususnya menyangkut penerapan teknologi pembuatan bokashi dan pemanfaatannya dalam pertanaman padi sawah dapat diukur melalui kegiatan evaluasi. Adapun maksud dari evaluasi tersebut adalah untuk mengetahui tingkat persepsi atau respon petani terhadap inovasi teknologi pembuatan bokashi dalam pemanfaatannya pada pertanaman padi sawah. Adapun penilaian evaluasi didasarkan pada proses adopsi inovasi kepada petani dengan mengacu pada lima tahapan gambaran alur penerimaan inovasi (Rogers, 1986 dalam Agustian A dan Benny R, 2009) yaitu: 


\section{a. Tahap Pengenalan}

Untuk tahap pengenalan, pada tahap ini petani merasa senang dan membuka diri terhadap adanya inovasi teknologi pembuatan bokashi, karena secara umum bahan bakunya berupa jerami padi mudah didapat.

\section{b. Tahap Persuasif}

Pada tahap ini petani mengambil keputusan untuk lebih ingin mengetahui inovasi teknologi pembuatan bokashi, dapat dilihat dimana petani terdorong untuk berkonsultasi lebih dalam untuk mencari keterangan atau informasi mengenai pembuatan bokashi dan teknik aplikasinya di lahan usahataninya.

\section{c. Tahap Keputusan}

Pada tahap ini, petani menerima atau menolak teknologi pembuatan Bokashi dan penggunaannya dalam pertanaman Padi Sawah. Kenyataan menunjukkan bahwa setelah petani mendapat informasi tentang keunggulan penggunaan organik dan dampak negative yang ditimbulkan oleh penggunaan pupuk anorganik, maka petani sebagian besar mengambil keputusan menerima dan mau menerapkannya di lahan usahatani padi sawah.

\section{d. Tahap Implementasi}

Pada tahap ini petani telah sering memanfaatkan bahan organik seperti jerami dan bahan organik lainnya sebagai pupuk organik, khususnya pada pertanaman padi sawah dengan cara membenamkan bahan organik kedalam tanah, selain itu petani memanfaatkan jerami sebagai mulsa untuk menekan atau menghambat gulma, selanjutnya setelah terjadi pelapukan, tanah akan menjadi gembur dan subur sehingga pertumbuhan tanaman menjadi baik. Pada tahap implementasi ini petani memutuskan untuk menindaklanjuti pemanfaatan bokashi dalam pertanaman padi sawah.

\section{e. Tahap Konfirmasi}

Pada tahap ini, petani lebih bersemangat lagi menerima dan memanfaatkan bokashi karean bila bokasi dimasukkan ke dalam tanah, bahan organiknya dapat digunakan sebagai pakan oleh mikroorganisme efektif untuk berkembangbiak dalam tanah, sekaligus sebagai tambahan persediaan unsur hara bagi tanaman. $\mathrm{EM}_{4}$ yang digunakan dalam pembuatan bokasi sangat berguna sekali dalam perbaikan sifat fisik, kimia, dan biologi tanah, juga dapat menekan pertumbuhan hama dan penyakit yang merugikan tanaman. Dengan demikian penggunaan pupuk bokasi memiliki prinsip ekologi sebagai berikut:Memperbaiki kondisi tanah sehingga menguntungkan pertumbuhan tanaman; Optimalisasi ketersediaan dan keseimbangan daur hara, melalui fiksasi nitrogen maupun penyerapan hara, Membatasi kehilangan hasil panen akibat hama dan penyakit, dan dapat disimpulkan bahwa dengan tersedianya nutrisi tanaman yang cukup dan aktivitas hama 
dan penyakit dapat ditekan, pertumbuhan dan produksi tanaman pertanian dapat meningkat baik kualitas maupun kuantitas. Selain itu penggunaan pupuk ini juga ramah lingkungan, produk yang dihasilkan tidak tercemar oleh bahan-bahan kimia yang membahayakan kesehatan dan lingkungan.

Untuk mengetahui sejauhmana tingkat respon petani terhadap teknologi pembuatan bokashi dan pemanfaatannya pada pertanaman padi sawah, maka dilakukan evaluasi dengan menggunakan skala sikap atau rating scale (skala nilai) dengan cara: memberikan pertanyaan kepada masing-masing petani responden kemudian diminta untuk memberikan jawaban dengan memilih satu angka dari alternatif angka-angka yang telah disediakan.

Adapun pertanyaan yang diberikan terhadap responden adalah sebagai berikut: Sejauhmana tingkat respon atau pemahaman terhadap teknologi pembuatan bokashi dan pemanfaatannya pada pertanaman padi sawah?

Jawaban dari petani tersebut kemudian diberi nilai dengan standarisasi tingkat respon/pemahaman sebagai berikut:

$4=$ Sangat respon

$3=$ Respon

$2=$ Cukup respon

$1=$ Tidak respon

$0=$ Sangat tidak respon

Hasil evaluasi tingkat respon/pemahaman teknologi pembuatan bokashi dan pemanfaatannya dalam pertanaman padi sawah yang dilakukan terhadap 25 orang petani responden adalah sebagai berikut:

Adapun skor yang diperoleh berdasarkan jawaban dari kuesioner adalah 360 , jumlah skor tertinggi jika semua pertanyaan dijawab dengan skor 4 adalah $=25 \times 5 \times 4=500$, jumlah skor terendah jika semua pertanyaan dijawab dengan skor $0=25 \times 5 \times 0=0$. Berdasarkan jumlah skor tersebut berarti kualitas tingkat respon atau pemahaman petani terhadap teknologi pembuatan bokashi dan pemanfaatannya dalam pertanaman padi sawah adalah

Total nilai $=(360 / 500) \times 100 \%=72,0 \%$

Hasil analisis data tersebut diatas menunjukkan bahwa tingkat keyakinan responden terhadap teknologi penggunaan pupuk Bokashi pada pertanaman Padi Sawah setelah mengikuti kegiatan penyuluhan sebesar 72,0\% dengan kategori "sangat respon". Hal ini menunjukkan kecenderungan responden untuk mengadopsi teknologi penggunaan pupuk Bokashi pada pertanaman Padi Sawah.

Jika digambarkan dalam bentuk garis kontinu adalah sebagai berikut:

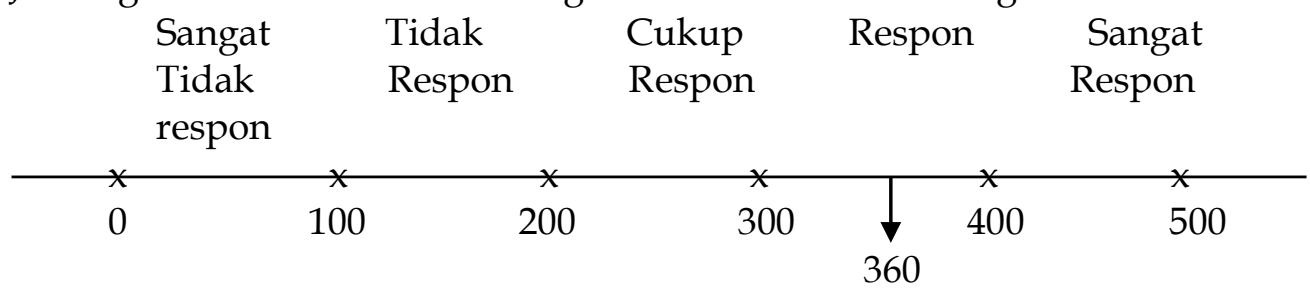


ISSN: 1412-8837

Gambar 1. Hasil evaluasi tingkat respon/pemahaman teknologi pembuatan bokashi dan pemanfaatannya pada pertanaman padi sawah di Desa Kuripan Kecamatan Penengahan, Kabupaten Lampung Selatan.

Berdasarkan Gambar 1 diatas dapat dijelaskan bahwa sebagian besar petani sangat respon atau memahami teknologi pembuatan bokashi dan pemanfaatannya dalam pertanaman padi sawah. Dari hasil evaluasi melalui 5 tahapan alur penerimaan inovasi yaitu tahap pengenalan, persuasif, keputusan, implementasi, dan tahap konfirmasi, maka didapat tingkat kualitas respon yaitu sebanyak 21 orang sangat respon $(72,0 \%)$ karena mereka sudah dapat membandingkan antara pemanfaatan bahan organik dan yang tidak memanfaatkan bahan organik dalam pertanaman padi sawah. Kemudian sebanyak 4 orang tidak respon yakni sebesar 28,0\% disebabkan karena minimnya informasi yang diperoleh responden dan belum terlalu yakin petani dalam menggunakan bahan organik dapat meningkatkan hasil usahataninya terutama padi sawah yang selama ini masih sangat tergantung dengan penggunaan sarana anorganik.

\section{SIMPULAN}

Tingkat adopsi petani terhadap inovasi teknologi pemanfaatan pupuk bokashi pada pertanaman padi sawah mencapai $72,00 \%$ sangat respon dan $28,00 \%$ tidak respon.

\section{DAFTAR PUSTAKA}

Agustian, A., dan Benny, R. 2006. Persepsi Petani terhadap Pemanfaatan Bokashi Jerami pada Tanaman Ubi Jalar. Jurnal Agrisistem. Volume 2. Hal. 46-53.

Nasir. 2008. Pengaruh Penggunaan Pupuk Bokasi pada Pertumbuhan dan Produksi Padi Palawija dan Sayuran. http://www.dispertanak. pandeglang.go.id/artikel

Nuhung, I.A., 2003. Membangun Pertanian Masa Depan, Suatu Gagasan Pembaharuan. Aneka Ilmu. Semarang.

Rochani, dkk. 2004. Persepsi Nelayan terhadap Jaring Ara di Kabupaten Batang. $h t t p: / / w w w$ portalgaruda.article.

Salikin. 2003. Sistem Pertanian Berkelanjutan. Kanisius. Yogyakarta.

Suparmin. 2007. Data Potensi Wilayah BPP Penengahan, Kecamatan Penengahan Lampung Selatan. 